\title{
New Neolignans and Lignans from Vietnamese Medicinal Plant Machilus odoratissima NEES
}

\author{
Phan Minh Giang, ${ }^{a, b}$ Phan Tong Son, ${ }^{a}$ Katsuyoshi Matsunami, ${ }^{b}$ and Hideaki OtsukA ${ }^{*, b}$ \\ ${ }^{a}$ Faculty of Chemistry, College of Natural Science, Vietnam National University; 19 Le Thanh Tong Street, Hanoi, \\ Vietnam: and ${ }^{b}$ Graduate School of Biomedical Sciences, Hiroshima University; 1-2-3 Kasumi, Minami-ku, Hiroshima \\ 734-8553, Japan. Received September 29, 2005; accepted November 24, 2005
}

Four new natural neolignans and lignans, which were given the trivial names odoratisols A-D (1-4), together with (-)-licarin A, kachirachirol B, obovatifol, and machilin-I were isolated from the air-dried bark of the Vietnamese medicinal plant Machilius odoratissima NeEs (Lauraceae). Their absolute structures were determined on the basis of spectroscopic analyses including circular dichroism spectra.

Key words Machilus odoratissima; Lauraceae; neolignan; lignan; odoratisol; absolute structure

Machilus is a genus in the Lauraceae family which includes twelve species distributed throughout Vietnam. They are Machilus odoratissima NEES, $M$. thunbergii SIEB. et Zucc., M. velutina Champ. ex. Benth., M. oreophila Hance, M. robutus J. J. Son., M. bonii LeC., M. coriacea A. CHev., M. thunbergii var. condorensis LEC., M. parviflora MeISSN., M. platycarpa Chun., M. macrophyla Hemsley, and $M$. cochinchinensis LEC. ${ }^{1-3)}$ Machilus odoratissima NeEs (Vietnamese name Khao nham) is a timber tree growing up to a height of $8-10 \mathrm{~m}$. The tree bark is used in the folk medicine as antiseptic and anti-inflammatory remedies. The leaves are used to treat snake bite and burn wounds. ${ }^{4)}$ We carried out the first systematic study on $M$. odoratissima dealing with the isolation and structural elucidation of four new and four known neolignans and lignans.

The bark of $M$. odoratissima was air-dried in the shadow, powdered, and extracted with $\mathrm{MeOH}$ at room temperature. The $\mathrm{MeOH}$ extract was partitioned between $\mathrm{H}_{2} \mathrm{O}$ and solvents of increasing polarities to afford $n$-hexane-, $\mathrm{CH}_{2} \mathrm{Cl}_{2}$-, EtOAc-, and 1-BuOH-soluble fractions. Column-chromatographic separation of the $n$-hexane- and $\mathrm{CH}_{2} \mathrm{Cl}_{2}$-soluble fractions led to the isolation of four new neolignans and lignans, named odoratisol $\mathrm{A}-\mathrm{D}(\mathbf{1}-\mathbf{4})$ and four known ones, $(-)$-licarin A, kachirachirol B, obovatifol, and machilin-I, which were determined by comparing their physical $\left([\alpha]_{\mathrm{D}}\right)$ and spectroscopic data with the literature values. ${ }^{5-9)}$

Odoratisol A (1) was isolated as an oil and its molecular formula was deduced to be $\mathrm{C}_{21} \mathrm{H}_{24} \mathrm{O}_{5}$ from negative-ion highresolution (HR)-FAB-MS. The IR spectrum indicated the presence of hydroxyl groups $\left(3450 \mathrm{~cm}^{-1}\right)$ and aromatic rings (1609, 1517, $\left.1458 \mathrm{~cm}^{-1}\right)$. The ${ }^{1} \mathrm{H}$ - (Table 1) and ${ }^{13} \mathrm{C}-\mathrm{NMR}$ (Table 2) spectroscopic data indicated that $\mathbf{1}$ had a planar structure of 5-methoxydehydrodiisoeugenol. The trans geometry of 1'-propenyl group was determined on the basis of the large coupling constant between $\mathrm{H}-7^{\prime}$ and $\mathrm{H}-\mathrm{8}^{\prime}$ $(J=15.6 \mathrm{~Hz})$. The trans relationship of $\mathrm{H}-7$ and H-8 was established based on ${ }^{1} \mathrm{H}-\mathrm{NMR}$ spectroscopic data characteristic of trans-7-aryl-8-methyl-7,8-dihydro-benzofuranoid-type neolignans $\left[\delta_{\mathrm{H}} 5.0(1 \mathrm{H}, \mathrm{d}, J=9.5 \mathrm{~Hz}, \mathrm{H}-7), 3.37(1 \mathrm{H}, \mathrm{dq}\right.$, $J=9.5,6.6 \mathrm{~Hz}, \mathrm{H}-8), 1.32(3 \mathrm{H}, \mathrm{d}, J=6.6 \mathrm{~Hz}, \mathrm{H}-9)] .^{10,11)}$ The positions of the methoxyl groups at $\delta_{\mathrm{H}} 3.81(3 \mathrm{H}, \mathrm{s})$ and 3.82 $(6 \mathrm{H}, \mathrm{s})$ were assigned using nuclear Overhauser effect spectroscopy (NOESY) (Fig. 2). 5-Methoxydehydrodiisoeugenol was reported previously from Myristica fragrans, ${ }^{12)}$ however, its stereochemistries at $\mathrm{C}-7$ and $\mathrm{C}-8$ have not been determined at that time. In this study the circular dichroism (CD) spectrum was used to determine the absolute configuration of 1 to be the $7 S, 8 S$ stereoisomer of 5-methoxydehydrodiisoeugenol from a positive Cotton effect at $242 \mathrm{~nm}(+4.35)$ and a negative one at $269 \mathrm{~nm}(-5.93)$, which were similar to those exhibited by $(-)$-licarin A. ${ }^{6}$ This configuration agreed well with the same sign of the optical rotations of $1\left([\alpha]_{\mathrm{D}}^{25}\right.$ $\left.-35.1^{\circ}\right)$ and $(-)$-licarin $\mathrm{A}\left([\alpha]_{\mathrm{D}}^{25}-44.0^{\circ}\right) .^{6)}$ Thus 1 was isolated for the first time from Nature and its absolute stereostructure was concluded to be $(7 S, 8 S)$-7,8-dihydro-7-(4-hy-<smiles>C/C=C/c1cc(OC)c2c(c1)C(C)C(c1cc(O)c(O)c(O)c1)O2</smiles><smiles>CC=Cc1ccc(OC(C)C(O)c2ccc(O)c(OC)c2)c(OC)c1</smiles>

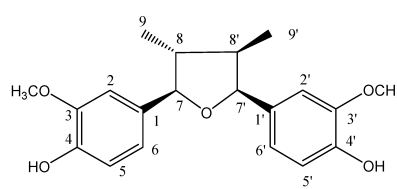

3

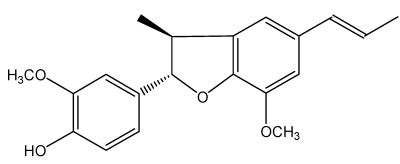

(-)-Licarin A

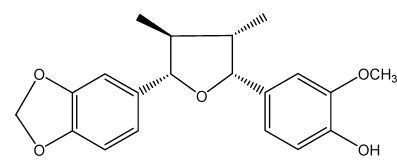

Austrobailignan-7

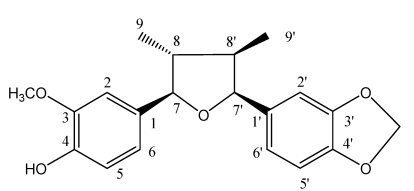

4

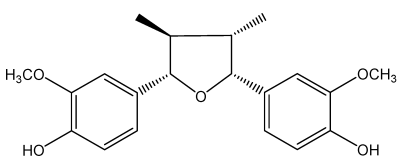

Verrucosin

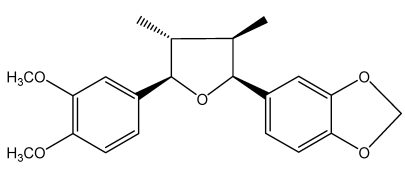

Futokadsurin B
Fig. 1. Absolute Structures of Compounds $\mathbf{1 - 4},(-)$-Licarin A, Verrucosin, Austrobailignan-7, and Futokadsurin B 
Table 1. ${ }^{1} \mathrm{H}-\mathrm{NMR}$ Spectroscopic Data of $\mathbf{1}-\mathbf{4}\left(\delta\right.$ in ppm, $J$ in $\mathrm{Hz}$ in Parentheses, $\left.400 \mathrm{MHz}, \mathrm{CDCl}_{3}\right)$

\begin{tabular}{cllll}
\hline \hline $\mathrm{H}$ & \multicolumn{1}{c}{$\mathbf{1}$} & \multicolumn{1}{c}{$\mathbf{2}$} & $\mathbf{3}$ & $\mathbf{4}$ \\
\hline 2 & $6.59 \mathrm{~s}$ & $6.84 \mathrm{~d}(2.0)$ & $6.97 \mathrm{~d}(1.7)$ & $6.95 \mathrm{~d}(1.7)$ \\
5 & & $6.78 \mathrm{~d}(8.5)$ & $6.84 \mathrm{~d}(8.3)$ & $6.83 \mathrm{~d}(8.3)$ \\
6 & $6.59 \mathrm{~s}$ & & $6.90 \mathrm{dd}(8.3,1.7)$ & $6.87 \mathrm{dd}(8.3,1.7)$ \\
7 & $5.0 \mathrm{~d}(9.5)$ & $4.75 \mathrm{~d}(3.2)$ & $4.31 \mathrm{~d}(9.3)$ & $4.27 \mathrm{~d}(9.3)$ \\
8 & $3.37 \mathrm{dq}(9.5,6.6)$ & $4.27 \mathrm{dq}(3.2,6.4)$ & $1.70 \mathrm{brdq}(9.3,6.6)$ & $1.68 \mathrm{brdq}(9.3,6.6)$ \\
9 & $1.32 \mathrm{~d}(6.6)$ & $1.09 \mathrm{~d}(6.4)$ & $0.98 \mathrm{~d}(6.6)$ & $0.95 \mathrm{~d}(6.6)$ \\
$2^{\prime}$ & $6.72 \mathrm{~s}$ & $6.91 \mathrm{~d}(2.0)$ & $6.78 \mathrm{~d}(1.7)$ & $6.70 \mathrm{~d}(1.7)$ \\
$5^{\prime}$ & & $6.88 \mathrm{~d}(8.3)$ & $6.80 \mathrm{~d}(8.0)$ & $6.71 \mathrm{~d}(8.0)$ \\
$6^{\prime}$ & $6.69 \mathrm{~s}$ & $6.84 \mathrm{dd}(8.3,2.0)$ & $6.74 \mathrm{dd}(8.0,1.7)$ & $5.79 \mathrm{dd}(8.0,1.7)$ \\
$7^{\prime}$ & $6.29 \mathrm{~d}(15.6)$ & $6.28 \mathrm{~d}(15.6)$ & $5.03 \mathrm{~d}(8.8)$ & $2.13 \mathrm{brdq}(8.8,7.1)$ \\
$8^{\prime}$ & $6.03 \mathrm{dq}(15.6,6.3)$ & $6.08 \mathrm{dq}(15.6,6.6)$ & $2.14 \mathrm{brdq}(8.8,6.8)$ & $0.59 \mathrm{~d}(7.1)$ \\
$9^{\prime}$ & $1.79 \mathrm{~d}(6.3)$ & $1.80 \mathrm{~d}(6.6)$ & $0.58 \mathrm{~d}(6.8)$ & $3.82 \mathrm{~s}$ \\
$\mathrm{MeO}-3$ & $3.82 \mathrm{~s}$ & $3.819 \mathrm{~s}$ & $3.82 \mathrm{~s}$ & \\
$\mathrm{MeO}-5$ & $3.82 \mathrm{~s}$ & & $3.77 \mathrm{~s}$ & $5.85 \mathrm{~s}$ \\
$\mathrm{MeO}-3^{\prime}$ & $3.81 \mathrm{~s}$ & $3.822 \mathrm{~s}$ & & \\
$\mathrm{OCH}_{2} \mathrm{O}$ & & & & \\
\hline
\end{tabular}

All assignments were made on the basis of heteronuclear single quantum correlation (HSQC) and NOESY experiments.

Table 2. ${ }^{13} \mathrm{C}-\mathrm{NMR}$ Spectroscopic Data of $\mathbf{1}-\mathbf{4}(\delta$ in ppm, $100 \mathrm{MHz}$, $\mathrm{CDCl}_{3}$ )

\begin{tabular}{crrrr}
\hline \hline C & $\mathbf{1}$ & $\mathbf{2}$ & $\mathbf{3}$ & $\mathbf{4}$ \\
\hline 1 & 133.2 & 133.8 & 133.2 & 132.5 \\
2 & 103.6 & 109.0 & 109.5 & 109.3 \\
3 & 147.1 & 146.5 & 146.6 & 146.55 \\
4 & 134.9 & 144.9 & 145.2 & 145.3 \\
5 & 147.1 & 113.9 & 114.2 & 114.3 \\
6 & 103.6 & 119.9 & 119.3 & 119.5 \\
7 & 94.0 & 82.4 & 87.4 & 82.8 \\
8 & 45.7 & 73.7 & 47.8 & 47.8 \\
9 & 17.6 & 13.4 & 14.9 & 15.0 \\
$1^{\prime}$ & 132.3 & 131.9 & 132.8 & 135.2 \\
$2^{\prime}$ & 109.5 & 109.5 & 109.8 & 120.2 \\
$3^{\prime}$ & 144.2 & 145.6 & 146.2 & 147.4 \\
$4^{\prime}$ & 146.6 & 151.6 & 144.6 & 146.59 \\
$5^{\prime}$ & 136.4 & 119.1 & 113.9 & 107.7 \\
$6^{\prime}$ & 113.3 & 118.8 & 119.9 & 107.5 \\
$7^{\prime}$ & 131.0 & 130.5 & 83.1 & 87.5 \\
$8^{\prime}$ & 123.5 & 125.0 & 46.0 & 45.9 \\
$9^{\prime}$ & 18.3 & 18.5 & 15.0 & 14.9 \\
$\mathrm{MeO}^{\prime} 3$ & 56.4 & 55.8 & 55.86 & 55.9 \\
$\mathrm{MeO}-5$ & 56.4 & & & \\
$\mathrm{MeO}^{\prime} 3^{\prime}$ & 56.0 & 55.9 & 55.9 & \\
$\mathrm{OCH}_{2} \mathrm{O}$ & & & & 100.9 \\
\hline
\end{tabular}

droxy-3,5-dimethoxyphenyl)-3'-methoxy-8-methyl-1'-transpropenylbenzofuran.

Odoratisol B (2) was isolated as an oil and had the molecular formula $\mathrm{C}_{20} \mathrm{H}_{24} \mathrm{O}_{5}$ based on negative-ion HR-FAB-MS. The IR spectrum indicated the presence of hydroxyl groups $\left(3448 \mathrm{~cm}^{-1}\right)$ and aromatic rings $\left(1603,1511,1458 \mathrm{~cm}^{-1}\right)$. The ${ }^{1} \mathrm{H}$ - (Table 1) and ${ }^{13} \mathrm{C}-\mathrm{NMR}$ (Table 2) spectroscopic data of 2 were superimposable with those of machilin $\mathrm{C}^{13)}$ including the erythro stereochemistry between $\mathrm{H}-7$ and $\mathrm{H}-8$ as shown by a small coupling constant $(J=3.2 \mathrm{~Hz})$ between them. However, the optical rotation of $2\left([\alpha]_{\mathrm{D}}^{25}+18.6^{\circ}\right)$ was almost of the same in value but reverse in sign in comparison with that of machilin $\mathrm{C}\left([\alpha]_{\mathrm{D}}^{25}-16.5^{\circ}\right)$ showing the need to determine the absolute stereochemistry at two stereogenic elements at C-7 and C-8. The CD spectrum of 2 showed positive Cotton effect at $258 \mathrm{~nm}(+0.38)$ established the configu-
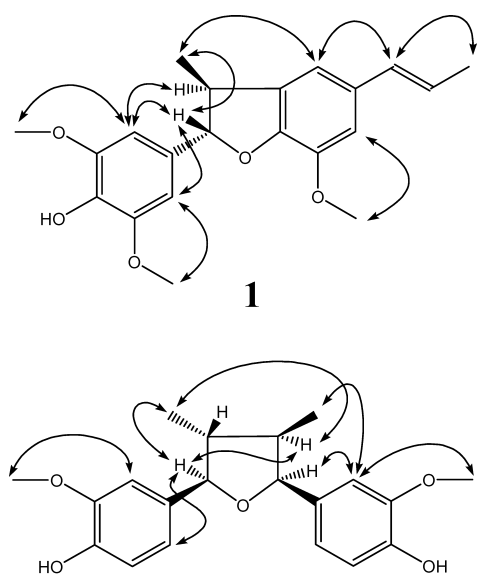

3

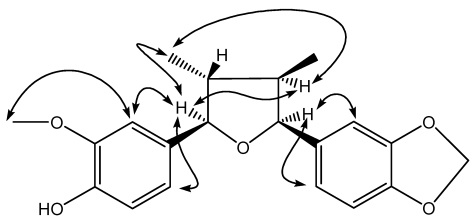

4

Fig. 2. NOESY Correlations of Compounds $\mathbf{1}, \mathbf{3}$, and $\mathbf{4}$

rations at C-7 an C-8 are $7 S$ and $8 R$ as in the cases of analogous neolignans of erythro series. ${ }^{14)}$ On the basis of these data, the structure of $\mathbf{2}$ was concluded to be $7 S, 8 R$-erythro-4hydroxy-3,2' -dimethoxy-4' -trans-propenyl-neolignan.

Odoratisol C (3) was isolated as an oil, $[\alpha]_{\mathrm{D}}^{25}-26.0^{\circ}$, and its molecular formula was characterized to be $\mathrm{C}_{20} \mathrm{H}_{24} \mathrm{O}_{5}$ in negative-ion HR-FAB-MS. The IR spectrum indicated the presence of hydroxyl groups $\left(3450 \mathrm{~cm}^{-1}\right)$ and aromatic rings (1607, 1514, $\left.1457 \mathrm{~cm}^{-1}\right)$. The ${ }^{1} \mathrm{H}$ - (Table 1) and ${ }^{13} \mathrm{C}-\mathrm{NMR}$ (Table 2) spectroscopic data showed the structural resemblance of $\mathbf{3}$ and verrucosin, ${ }^{15)}$ which, however, displayed a positive optical rotation $\left([\alpha]_{\mathrm{D}}+14.8^{\circ}\right)$. The trans $\mathrm{H}-7 / \mathrm{H}-8$, trans $\mathrm{H}-8 / \mathrm{H}-8^{\prime}$, and cis $\mathrm{H}-7^{\prime} / \mathrm{H}-8^{\prime}$ relative stereochemistries of the tetrahydrofuran ring were determined by comparing 
the ${ }^{1} \mathrm{H}-\mathrm{NMR}$ data $\left[\delta_{\mathrm{H}} 0.98(3 \mathrm{H}, \mathrm{d}, J=6.6 \mathrm{~Hz}, \mathrm{H}-9), 1.70(1 \mathrm{H}\right.$, br dq, $J=9.3,6.6 \mathrm{~Hz}, \mathrm{H}-8), 4.31(1 \mathrm{H}, \mathrm{d}, J=9.3 \mathrm{~Hz}, \mathrm{H}-7)$; $0.58\left(3 \mathrm{H}, \mathrm{d}, J=6.8 \mathrm{~Hz}, \mathrm{H}-9^{\prime}\right), 2.14(1 \mathrm{H}$, br dq, $J=8.8,6.8$ $\left.\left.\mathrm{Hz}, \mathrm{H}-8^{\prime}\right), 5.03\left(1 \mathrm{H}, \mathrm{d}, J=8.8 \mathrm{~Hz}, \mathrm{H}-7^{\prime}\right)\right]$ with those reported in literature for 7,8 -trans-8, $8^{\prime}$-trans- $7^{\prime}, 8^{\prime}$-cis-configurated tetrahydrofuran-type lignans. ${ }^{15-17)}$ The trans $\mathrm{H}-7 / \mathrm{H}-8$ and cis $\mathrm{H}-7^{\prime} / \mathrm{H}-8^{\prime}$ configurations were in agreement with the upfield shift $\left(\Delta \delta_{\mathrm{H}}-0.4\right)$ of methyl proton signals on going from C-9 to $\mathrm{C}-9^{\prime}$ due to the anisotropic effect of the aromatic group in the case of the cis-configuration of the aryl group at C-7' and methyl substituent at $\mathrm{C}-8^{\prime}$. The stereochemical assignments were supported by the NOESY spectrum (Fig. 2) of $\mathbf{3}$, which showed NOEs between $\mathrm{H}_{3}-9\left(\delta_{\mathrm{H}} 0.98\right)$ and $\mathrm{H}-7\left(\delta_{\mathrm{H}} 4.31\right)$, between $\mathrm{H}_{3}-9$ and $\mathrm{H}-8^{\prime}\left(\delta_{\mathrm{H}} 2.14\right)$, and between $\mathrm{H}-7$ and $\mathrm{H}-8^{\prime}$, between $\mathrm{H}_{3}-9^{\prime}\left(\delta_{\mathrm{H}} 0.58\right)$ and $\left.\mathrm{H}-2^{\prime}\left(\delta_{\mathrm{H}} 6.78\right) .{ }^{17,18}\right)$ The locations of two 4-hydroxy-3-methoxyphenyl moieties were also confirmed by NOEs between H-6 [ $\delta_{\mathrm{H}} 6.90$ (dd, $J=8.3$, $1.7 \mathrm{~Hz})]$ and $\mathrm{H}-7$ and between $\mathrm{H}-2^{\prime}\left[\delta_{\mathrm{H}} 6.78(\mathrm{~d}, J=1.7 \mathrm{~Hz})\right]$ and $\mathrm{H}^{-} \mathbf{7}^{\prime}$. Since 3 had the same relative stereochemistry but opposite optical rotation in comparison with those of verrucosin, the absolute configurations at the $\mathrm{C}-7, \mathrm{C}-8, \mathrm{C}-7^{\prime}$, and C- $8^{\prime}$ were deduced to be opposite to those of verrucosin. Thus the absolute structure of $\mathbf{3}$ was determined to be $\left(7 R, 8 R, 7^{\prime} S, 8^{\prime} R\right)$-4-hydroxy-3-methoxy-4' -hydroxy-3' methoxy-7,7'-epoxylignan.

Odoratisol D (4) was isolated as an oil and its molecular formula was determined $\mathrm{C}_{20} \mathrm{H}_{22} \mathrm{O}_{5}$ by means of negative-ion HR-FAB-MS. The IR spectrum indicated the presence of hydroxyl groups $\left(3450 \mathrm{~cm}^{-1}\right)$ and aromatic rings $(1608,1517$, $1442 \mathrm{~cm}^{-1}$ ). The ${ }^{1} \mathrm{H}-\mathrm{NMR}$ (Table 1) spectrum showed the presence of a 4-hydroxy-3-methoxyphenyl and a monosubstituted 3,4-methylenedioxyphenyl systems, which contained an aromatic methoxyl group $\left[\delta_{\mathrm{H}} 3.82(3 \mathrm{H}, \mathrm{s})\right]$ and a methylenedioxy group $\left[\delta_{\mathrm{H}} 5.85(2 \mathrm{H}, \mathrm{s})\right]$, and a 2,5 -disubstituted 3,4-dimethyltetrahydrofuran ring $\left[\delta_{\mathrm{H}} 0.95(3 \mathrm{H}, \mathrm{d}, J=6.6 \mathrm{~Hz}, \mathrm{H}-9)\right.$, $1.68(1 \mathrm{H}$, br dq, $J=9.3,6.6 \mathrm{~Hz}, \mathrm{H}-8), 4.27(1 \mathrm{H}, \mathrm{d}, J=9.3 \mathrm{~Hz}$, $\mathrm{H}-7) ; 0.59\left(3 \mathrm{H}, \mathrm{d}, J=7.1 \mathrm{~Hz}, \mathrm{H}-9^{\prime}\right), 2.13(1 \mathrm{H}, \mathrm{br} \mathrm{dq}, J=8.8$, $\left.\left.7.1 \mathrm{~Hz}, \mathrm{H}-8^{\prime}\right), 5.01\left(1 \mathrm{H}, \mathrm{d}, J=8.8 \mathrm{~Hz}, \mathrm{H}-7^{\prime}\right)\right]$. The ${ }^{1} \mathrm{H}-$ and ${ }^{13} \mathrm{C}$-NMR (Table 2) spectroscopic data of $\mathbf{4}$ resembled those of futokadsurin $\mathrm{B}^{18)}$ except for the lack of an additional methoxyl group. The trans $\mathrm{H}-7 / \mathrm{H}-8$, trans $\mathrm{H}-8 / \mathrm{H}-8^{\prime}$, and cis $\mathrm{H}-7^{\prime} / \mathrm{H}-8^{\prime}$ relative stereochemistry of the tetrahydrofuran ring were conclusive on the basis of the comparison of the ${ }^{1} \mathrm{H}-\mathrm{NMR}$ data with those reported in literature. ${ }^{16-19)}$ Upfield shift $\left(\Delta \delta_{\mathrm{H}}-0.36\right)$ of methyl proton signals on going from $\mathrm{C}$ 9 to $\mathrm{C}-9^{\prime}$ agreed with trans $\mathrm{H}-7 / \mathrm{H}-8$ and $c i s \mathrm{H}-7^{\prime} / \mathrm{H}-8^{\prime}$ configurations. NOEs observed between $\mathrm{H}_{3}-9\left(\delta_{\mathrm{H}} 0.95\right)$ and $\mathrm{H}-7$ $\left(\delta_{\mathrm{H}} 4.27\right)$, between $\mathrm{H}_{3}-9$ and $\mathrm{H}-8^{\prime}\left(\delta_{\mathrm{H}} 2.13\right)$, and between $\mathrm{H}-$ 7 and $\mathrm{H}-8^{\prime}$, but not between $\mathrm{H}_{3}-9^{\prime}\left(\delta_{\mathrm{H}} 0.59\right)$ and $\mathrm{H}-7^{\prime}\left(\delta_{\mathrm{H}}\right.$ 5.01) supported the stereochemical assignments. ${ }^{17)}$ Thus 4 was concluded to have the same relative stereochemistry as that of 3. NOESY spectrum (Fig. 2) of $\mathbf{4}$ showed the correlations between the methoxyl group $\left(\delta_{\mathrm{H}} 3.82\right)$ and $\mathrm{H}-2$, between H-2 $\left(\delta_{\mathrm{H}} 6.95\right)$ and H-7 $\left(\delta_{\mathrm{H}} 4.27\right)$, between H-6 $\left(\delta_{\mathrm{H}}\right.$ $6.87)$ and $\mathrm{H}-7$, between $\mathrm{H}-2^{\prime}\left(\delta_{\mathrm{H}} 6.70\right)$ and $\mathrm{H}-7^{\prime}\left(\delta_{\mathrm{H}} 5.01\right)$, and between $\mathrm{H}-6^{\prime}\left(\delta_{\mathrm{H}} 6.79\right)$ and $\mathrm{H}-7^{\prime}$ confirmed the assignments of the position of the 4-hydroxy-3-methoxyphenyl moiety at C-7 and the $3^{\prime}, 4^{\prime}$-methylenedioxyphenyl moiety at C-7' as shown in Fig. 2. To establish the absolute structure of $\mathbf{4}$ the CD spectra of $\mathbf{3}$ and $\mathbf{4}$ were measured and compared. Similar CD curves of $\mathbf{3}$ and $\mathbf{4}$ were seen, namely, $\mathbf{4}$ displayed the Cotton effects at $213 \mathrm{~nm}(-1.25), 240 \mathrm{~nm}(+0.95)$, and $285 \mathrm{~nm}(-0.40)$ assuring the absolute structure of 4 to be $\left(7 R, 8 R, 7^{\prime} S, 8^{\prime} R\right)$-4-hydroxy-3-methoxy-3',4'-methylenedioxy-7,7'-epoxylignan.

\section{Experimental}

General Procedure Optical rotations were measured on a JASCO P1030 polarimeter. FT-IR spectra were recorded on a Horiba FT-710 spectrophotometer. ${ }^{1} \mathrm{H}-(400 \mathrm{MHz})$ and ${ }^{13} \mathrm{C}-\mathrm{NMR}(100 \mathrm{MHz})$ spectra were recorded using a JEOL JNM- $\alpha 400$ NMR spectrometer with tetramethylsilane as an internal standard. Negative-ion HR-FAB-MS were measured on a JEOL SX-102 mass spectrometer with PEG-400 as a calibration matrix. HPLC was carried out with a JASCO PU-1580 pump and an UV-2075 Plus detector (set at $210 \mathrm{~nm})$ on YMC ODS columns $(150 \times 4.6 \mathrm{~mm}$ i.d. in analytical and $150 \times 20 \mathrm{~mm}$ i.d. in preparative scales) at the corresponding flow rates of 0.5 and $5 \mathrm{ml} / \mathrm{min}$. Silica (Si) gel $60(0.063-0.200 \mathrm{~mm}$, Merck, Germany) and reversed-phase octadecyl Si (ODS) gel (YMC, Japan) were used for open-column chromatography. TLC was carried out on Merck TLC plates ( $\mathrm{Si}$ gel $60 \mathrm{~F}_{254}$ ), and detected by spraying with $10 \% \mathrm{H}_{2} \mathrm{SO}_{4}$ in $50 \%$ $\mathrm{EtOH}$, followed by heating on a hot plate at $200^{\circ} \mathrm{C}$.

Plant Material The air-dried bark $(2.0 \mathrm{~kg})$ of $M$. odoratissima was collected in Province Thai Nguyen, Vietnam, and identified by Dr Nguyen Hoanh Coi of the Military Institute of Drug Controls (Hanoi, Vietnam), in June 2000. A voucher specimen (no. HCTN 2000-6) is deposited in the Laboratory of Chemistry of Natural Products, Faculty of Chemistry, Vietnam National University, Hanoi, Vietnam.

Extraction and Isolation of $\mathbf{1 - 1 0}$ The powdered air-dried bark of $M$. odoratissima $(2.0 \mathrm{~kg})$ was extracted with $\mathrm{MeOH}$ by percolation at room temperature ( 3 times, for $3 \mathrm{~d}$ each). After concentration by evaporation under reduced pressure, the resultant $\mathrm{MeOH}$ extract was suspended in $\mathrm{H}_{2} \mathrm{O}$ and sequentially extracted with $n$-hexane, $\mathrm{CH}_{2} \mathrm{Cl}_{2}$, EtOAc, and 1-BuOH. The nhexane-soluble fraction $(5.9 \mathrm{~g})$ was separated on a Si gel open column using mixtures of $n$-hexane in EtOAc $(10: 1,4: 1,2: 1,1: 1)$. Five pooled fractions were collected on the basis of TLC pattenrs. Fraction 2 (1.8 g), fraction $3(0.5 \mathrm{~g})$, and fraction $4(0.4 \mathrm{~g})$ underwent the same treatment, first separation on an ODS gel open column $\left(\mathrm{MeOH}-\mathrm{H}_{2} \mathrm{O}, 3: 1,4: 1\right)$, then purification on ODS preparative HPLC $\left(\mathrm{MeOH}-\mathrm{H}_{2} \mathrm{O}, 3: 1\right)$ to give odoratisol A (1, $12.2 \mathrm{mg})$, odoratisol B (2,7.0 mg), odoratisol C (3, $27.9 \mathrm{mg})$, odoratisol D $(4,40.2 \mathrm{mg}),(-)$-licarin A $(0.48 \mathrm{~g})$, machilin-I $(13.4 \mathrm{mg})$, kachirachirol B $(16.1 \mathrm{mg})$, and obovatifol $(17.8 \mathrm{mg})$. Similar procedure was used to separate the $\mathrm{CH}_{2} \mathrm{Cl}_{2}$-soluble fraction yielding $1(7.9 \mathrm{mg}),(-)$-licarin A $(55.8 \mathrm{mg})$, and kachirachirol B (56.4 mg).

Odoratisol A (1): Oil, $[\alpha]_{\mathrm{D}}^{25}-35.1^{\circ}\left(c=1.22, \mathrm{CHCl}_{3}\right)$. UV $\lambda_{\max }(\mathrm{MeOH})$ $\mathrm{nm}(\log \varepsilon): 270$ (4.18), 219 (4.43). IR $v_{\max }$ (film) $\mathrm{cm}^{-1}: 3450,2957,2926$, 2854, 1609, 1517, 1493, 1458, 1375, 1078. CD (MeOH): $\Delta \varepsilon(\mathrm{nm}):-2.14$ (218), +4.35 (242), -5.93 (269) $\left(c=2.0 \times 10^{-5} \mathrm{M}\right) .{ }^{1} \mathrm{H}$ - and ${ }^{13} \mathrm{C}-\mathrm{NMR}$ : see Tables 1 and 2. Negative-ion HR-FAB-MS: $m / z$ 355.1544 [M-H] ${ }^{-}$(Calcd for $\left.\mathrm{C}_{21} \mathrm{H}_{23} \mathrm{O}_{5}: 355.1545\right)$.

Odoratisol B (2): Oil, $[\alpha]_{\mathrm{D}}^{25}+18.6^{\circ}\left(c=0.70, \mathrm{CHCl}_{3}\right)$. UV $\lambda_{\max }(\mathrm{MeOH})$ $\mathrm{nm}(\log \varepsilon): 258(3.68), 218(3.87)$. IR $v_{\max }\left(\right.$ film) $\mathrm{cm}^{-1}: 3448,2957,2925$, 2854, 1603, 1511, 1458, 1377, 1061. $\mathrm{CD}(\mathrm{MeOH}): \Delta \varepsilon(\mathrm{nm}):-0.74(219)$, $+0.38(258),+0.18(350)\left(c=4.2 \times 10^{-5} \mathrm{M}\right) .{ }^{1} \mathrm{H}-$ and ${ }^{13} \mathrm{C}-\mathrm{NMR}$ : see Tables 1 and 2. Negative-ion HR-FAB-MS: $m / z 343.1523[\mathrm{M}-\mathrm{H}]^{-}$(Calcd for $\left.\mathrm{C}_{20} \mathrm{H}_{23} \mathrm{O}_{5}: 343.1545\right)$.

Odoratisol C (3): Oil, $[\alpha]_{\mathrm{D}}^{25}-26.0^{\circ}\left(c=2.79, \mathrm{CHCl}_{3}\right)$. UV $\lambda_{\max }(\mathrm{MeOH})$ $\mathrm{nm}(\log \varepsilon): 280(3.71), 232$ (4.05). IR $v_{\max }$ (film) $\mathrm{cm}^{-1}: 3450,2958,2926$ 2854, 1607, 1514, 1457, 1377, 1033. CD (MeOH): $\Delta \varepsilon(\mathrm{nm}):-4.37$ (211), $+0.31(258),-0.38(281)\left(c=4.3 \times 10^{-5} \mathrm{M}\right) .{ }^{1} \mathrm{H}-$ and ${ }^{13} \mathrm{C}-\mathrm{NMR}$ : see Tables 1 and 2. Negative-ion HR-FAB-MS: $m / z 343.1542[\mathrm{M}-\mathrm{H}]^{-}$(Calcd for $\left.\mathrm{C}_{20} \mathrm{H}_{23} \mathrm{O}_{5}: 343.1545\right)$.

Odoratisol D (4): Oil, $[\alpha]_{\mathrm{D}}^{25}-12.8^{\circ}\left(c=4.0, \mathrm{CHCl}_{3}\right)$. UV $\lambda_{\max }(\mathrm{MeOH})$ $\mathrm{nm}(\log \varepsilon): 282$ (3.80), 234 (3.97). IR $v_{\max }$ (film) $\mathrm{cm}^{-1}: 3450,2959,2927$ 2873, 1608, 1517, 1488, 1442, 1377, 1036. CD (MeOH): $\Delta \varepsilon(\mathrm{nm}):-1.25$ (213), $+0.95(240),-0.40(285)\left(c=8.8 \times 10^{-5} \mathrm{M}\right) .{ }^{1} \mathrm{H}-$ and ${ }^{13} \mathrm{C}-\mathrm{NMR}$ : see Tables 1 and 2. Negative-ion HR-FAB-MS: $m / z$ 341.1401 [M-H] ${ }^{-}$(Calcd for $\mathrm{C}_{20} \mathrm{H}_{21} \mathrm{O}_{5}: 341.1389$ ).

Acknowledgments This work was supported by a Grant-in-Aid from the Japan Society for the Promotion of Science (JSPS). P.M.G. is grateful to acknowledge the JSPS for a Postdoctoral Research Fellowship at Hiroshima University and the International Foundation for Science (Stockholm, Sweden) for a research grant. We thank the Research Center of the Graduate School of Biomedical Sciences, Hiroshima University, Japan, for the meas- 
urements on its $400 \mathrm{MHz}$ NMR instrument

\section{References}

1) Pham H. H., "Illustrated Flora of Vietnam," Tom 1, Fascile 1, Published by the Author, Montreal, 1991, pp. 488-492.

2) Le K. K., "Common Flora of Vietnam," Vol. 2, Science and Technique, Hanoi, 1971, pp. 265-266.

3) Do T. L., "Medicinal Plants and Remedies of Vietnam," Science and Technique, Hanoi, 1995, pp. 666-668.

4) Nguyen D. M., “Anti-infective Drugs from Plants of Vietnam," Medicine, Ho Chi Minh city, 1995, pp. 105-109.

5) Aiba C. J., Campos Corrêa R. G., Gottlieb O. R., Phytochemistry, 12, $1163-1164$ (1973).

6) Nascimento I. R., Lopes L. M. X., Davin L. B., Lewis N. G., Tetrahedron, 56, 9181-9193 (2000).

7) Ito K., Ichino K., Iida J., Lai J., Phytochemistry, 23, 2643-2645 (1984).

8) Tsai I. L., Hsieh C. F., Duh C. Y., Phytochemistry, 48, 1371-1375 (1998).

9) Shimomura H., Sashida Y., Oohara M., Phytochemistry, 27, 634-636
(1988).

10) Benevides P. J. C., Sartorelli P., Kato M. J., Phytochemistry, 52, 339343 (1999).

11) Nascimento I. R., Lopes L. M. X., Phytochemistry, 52, 345-350 (1999).

12) Forrest J. E., Heacock R. A., Forrest T. P., J. Chem. Soc. Perkin Trans. I, 1974, 205-209 (1974).

13) Shimomura H., Sashida Y., Oohara M., Phytochemistry, 26, 1513 1515 (1987).

14) Matsuda N., Kikuchi M., Chem. Pharm. Bull., 44, 1676-1679 (1996).

15) Hattori M., Hada S., Kawata Y., Tezuka Y., Kikuchi T., Namba T., Chem. Pharm. Bull., 35, 3315-3322 (1987).

16) Kraft C., Jenett-Siems K., Köhler I., Tofern-Reblin B., Siems K., Bienzle U., Eich E., Phytochemistry, 60, 167-173 (2002).

17) Urzúa A., Freyer A. J., Shamma M., Phytochemistry, 26, 1509-1511 (1987).

18) Konishi T., Konoshima T., Daikonya A., Kitanaka S., Chem. Pharm. Bull., 53, 121-124 (2005).

19) Hada S., Hattori M., Tezuka Y., Kikuchi T., Namba T., Phytochemistry, 27, 563-568 (1988). 